\title{
Plagiarism: A Global Phenomenon
}

\author{
Nur-E Hafsa \\ School of Arts and Social Sciences, Department of English, Southeast University, Bangladesh
}

\begin{abstract}
Academic writing is specially a challenging task for ESL/EFL students as it entails an assortment of cognitive and linguistic processes which is beyond their capability. Consequently, to fulfill the writing requirement of academia, an unexperienced writer very often ventures to make use of other peoples' words and ideas without citing the source-a practice commonly known as "plagiarism". Scholars have traced various kinds of plagiarism in student academic writing. However, there exists an underlying contradiction among the scholars regarding the reasons for plagiarism in academic writing committed by students. One segment of researchers believes students as exclusively liable for committing plagiarism. On the Contrary, the researchers with opposite views, underscore the concern of responsibility of educational institutions and academics. This article aims to collate seminal works on plagiarism which concentrate on the aspects- reasons, and types of plagiarism, and the role of education institutions to minimize plagiarism.
\end{abstract}

Keywords: academic writing, plagiarism, reason, types, institution role.

DOI: $10.7176 / \mathrm{JEP} / 12-3-08$

Publication date: January $31^{\text {st }} 2021$

\section{Introduction}

Academic writing has become the focus of academics due to the upgoing trend of enrollment for higher education and advent of English as the lingua franca of research and knowledge seeking (Hyland, 2013). Before entering the world of academic study students need to demonstrate proficiencies in various areas like- improving verbal communication (Kim, 2011), developing critical analyzing skills (Ravichandran, Kretovics, Kirby, \& Ghosh, 2017), and mastering discipline focused academic writing style in English (Evans \& Green, 2007; Phakiti \& Li, 2011). Academic writing is specially a challenging task for ESL/EFL students as it entails an assortment of cognitive and linguistic processes which is beyond their capability (Luchini, 2010). Consequently, to fulfill the writing requirement of academia, an unexperienced writer ventures to make use of other peoples' words and ideas without citing the source-a practice commonly known as "plagiarism", a kind of academic misconduct (Bretag, 2013).

In terms of types of plagiarism, various scholars have indicated different types of plagiarism existent in student academic writing. The most frequent category of plagiarism mentioned was devised by Walker (2010), namely- sham (word to word copying without citing the source), verbatim (exact copying of words without any source citation), and purloining (word to word copying another person's work). Wan et al., (2011) divides plagiarism in five types, namely- direct text copying, "patchwork", paraphrasing, truncation, excision etc. Some other types are- self-plagiarism (Scanlon, 2007)- submitting one's own original work for different purposes; copying from other students of the same school (Howard, 1995); buying articles from-paper mills- online essay writing service providers (Szabo \& Underwood, 2004).

However, there exists an underlying contradiction among the scholars regarding the reasons for plagiarism in academic writing committed by students. One segment of researchers believes students as exclusively liable for committing plagiarism. By this group of researchers, students'- dearth of knowledge and skill in source crediting (Newton, Wright, \& Newton ,2014; Voelker, Love, \& Pentina , 2012), inefficient time allocation, engagement with activities other than study (Kayaoglu, Erbay, Flitner \& Saltas , 2016), procrastination- (Foltynek, Rybicka \& Demoliou, 2014), ineptitude in academic writing (Batane , 2010; De Jager \& Brown, 2010), lack of moral obligation (Khadilkar, 2018), achieving credit (Wei et al, 2014)- are cited as key reasons of plagiarism.

Conversely, the researchers with opposite views, underscore the concern of responsibility of educational institutions and academics. Pecorari \& Petric (2014) highlights on endowing students with basic knowledge and skill to cope with academic writing requirements of the tertiary level. The findings of the project of Foltynek, Rybicka \& Demoliou (2014) investigating into plagiarism policies, procedures, prevention, and penalties at several higher education institutions in EU countries in Europe, discovered that some of the universities do not provide students with the essential knowledge to discard plagiarism. This research indicates that HEI (Higher education institution) educators should nurture a supportive attitude on students' academic writing requirements and initiate to create an awareness of plagiarism amongst students. As highlighted by MacLennan (2018)- only expressing a hostile approach towards students who committed plagiarism cannot put an end to the problem. Contrastively, she recommends specific tutoring of plagiarism deterrence skills- which may play a crucial role in minimizing plagiarism trend among students. 


\section{Types of plagiarism}

Diane Pecorari (2010) has differentiated plagiarism in two types based on "presence or absence" of deliberate dishonesty. The first one is -"prototypical plagiarism" which is defined as- "the use of words and/or ideas from another source, without appropriate attribution, and with the intention to deceive" (Pecorari, 2010, p.4). The other type of plagiarism where the element of purposeful deception is absent, has been termed as "patch writing" by Rebecca Howard (1995, 1999). As identified by Howard (1995, 1999), patch writing involves: "copying from a source text and then deleting some words, altering grammatical structures, or plugging in one synonym for another" (1999, p. xvii).

Pritchett (2010) categorizes plagiarism in two types, one is "paraphrasing plagiarism" and the other is -"word for word plagiarism". Interestingly, students who plagiarize verbatim can be identified without much effort and penalized more than students who plagiarize at paraphrasing level as it is very difficult for academics to scrutinize plagiarism in that form (Martin, 1994).

Irrespective of the variation in the categories of plagiary, most scholars in the field have asserted that plagiarism can be "conscious or unconscious" (Pritchett, 2010; Pre \& Belter, 2009; Logue, 2004) and these two varieties arise from individual's consciousness about it. However, students' unacquaintance of source acknowledgement aspect does not eliminate its unethical connotations (Logue, 2004). Influential studies on plagiarism types have been presented in Table 1.

\section{Causes of plagiarism}

Various factors ranging from scientific progress and teaching practices to cultural and social influences have been recorded in the literature as contributing to the occurrences of plagiarism. Scholars attribute plethora of electronic resources and trouble-free availability of these materials through internet as one of the vital reasons for students resorting to plagiary (Pre \& Belter, 2009; Wang, 2008; Howard, 2007; Salgado, \& Bassendowski, 2005). Taking help of internet for academic needs is mentioned as the main reason of plagiarism by Howard (2007). Teaching the basic skills of reading, writing, source acknowledging can eventually be discouraging for the academics due to the abuse of source utilization from internet by the students (Howard, 2007).

In some studies, it has been mentioned that students plagiarize as they have vague conception about citing and quoting sources (Pritchett, 2010; Pre \& Belter, 2009; Logue, 2004). Moreover, many students lack the perception of considering paraphrasing plagiarism and other types of plagiarism as deception (Pritchett, 2010).

Lack of academic skill has been asserted as one of the main reasons for adopting the habit of plagiarizing among students (Pre \& Belter, 2009). From the findings of their studies Pre \& Belter (2009) concluded that when students are given assignments that require skill and knowledge above their capability, the probability of plagiarism becomes higher.

Laziness or indolence has also been identified as another factor behind plagiarism by some scholars. Tommaso and Roig (1995) suggested an intense association between "procrastination and plagiarism".

Table 1: Types of plagiarism.

\begin{tabular}{|c|c|c|c|c|}
\hline SI & Year & Author/source & \multicolumn{2}{|c|}{ Types of plagiarism } \\
\hline \multirow[t]{10}{*}{01.} & \multirow[t]{10}{*}{2016} & \multirow[t]{10}{*}{$\begin{array}{l}\text { Turnitin White } \\
\text { Paper }\end{array}$} & Clone & $\begin{array}{l}\text { Submitting another's work, word for word, as } \\
\text { one's own. }\end{array}$ \\
\hline & & & $\mathrm{CTRL}+\mathrm{C}$ & $\begin{array}{l}\text { Contains significant portions of text from a single } \\
\text { source without alterations }\end{array}$ \\
\hline & & & Find-Replace & $\begin{array}{l}\text { Changing key words and phrases but retaining the } \\
\text { essential content of the source. }\end{array}$ \\
\hline & & & Remix & $\begin{array}{l}\text { Paraphrases from multiple sources, made to fit } \\
\text { together. }\end{array}$ \\
\hline & & & Recycle & $\begin{array}{l}\text { Borrows generously from the writer's pervious } \\
\text { work without citation. }\end{array}$ \\
\hline & & & Hybrid & $\begin{array}{l}\text { Combines perfectly cited sources with copied } \\
\text { passages without citation }\end{array}$ \\
\hline & & & Mashup & Mixes copied materials from multiple sources. \\
\hline & & & 404 Error & $\begin{array}{l}\text { Incudes citations to non- existent or inaccurate } \\
\text { information about sources. }\end{array}$ \\
\hline & & & Aggregator & $\begin{array}{l}\text { Includes proper citation to sources but the paper } \\
\text { contains almost no original work. }\end{array}$ \\
\hline & & & Re -Tweet & $\begin{array}{l}\text { Includes proper citation but relies too closely on } \\
\text { the text's original wording and/or structure. }\end{array}$ \\
\hline
\end{tabular}




\begin{tabular}{|c|c|c|}
\hline \multirow[t]{10}{*}{02.} & $\begin{array}{l}\text { 1) Secondary sources } \\
\text { (Inaccurate Citation) }\end{array}$ & $\begin{array}{l}\text { When a researcher uses a secondary source, like a } \\
\text { meta -study, but only cites the primary-sources, } \\
\text { contained within the secondary one. Secondary } \\
\text { source plagiarism not only fails to attribute the } \\
\text { work of the authors of the secondary-sources, but } \\
\text { also provides a false sense of the amount of review, } \\
\text { that went into the research. }\end{array}$ \\
\hline & $\begin{array}{l}\text { 2) Invalid Source } \\
\text { (Misleading-citations, } \\
\text { Fabrication, and } \\
\text { Falsification) }\end{array}$ & $\begin{array}{l}\text { Occurs when researchers reference either an } \\
\text { incorrect or nonexistent-source. Though this may } \\
\text { be the result of sloppy research, rather than intent } \\
\text { to deceive, it can also be an attempt to increase the } \\
\text { list of references and hide inadequate research. }\end{array}$ \\
\hline & $\begin{array}{l}\text { 3) Duplication (Self- } \\
\text { plagiarism, Reuse) }\end{array}$ & $\begin{array}{l}\text { Happens, when a researcher reuses work from } \\
\text { their-previous studies and papers, without } \\
\text { attribution. The ethics of duplication is highly } \\
\text { debated, and often depends upon the content } \\
\text { copied. }\end{array}$ \\
\hline & $\begin{array}{l}\text { 4) Paraphrasing } \\
\text { (Plagiarism, Intellectual } \\
\text { theft) }\end{array}$ & $\begin{array}{l}\text { Taking another's person's writing and changing } \\
\text { the words, making it appears that an idea, or even } \\
\text { a piece of research, is original, when, in truth, it } \\
\text { came from an incited-outside-source. It ranges } \\
\text { from the simple-rephrasing to completely } \\
\text { rewriting content, while maintaining the original- } \\
\text { idea or concept. }\end{array}$ \\
\hline & $\begin{array}{l}\text { 5) Repetitive Research } \\
\text { (Self-plagiarism, Reuse) }\end{array}$ & $\begin{array}{l}\text { Repeating of data or text, from a similar-study with } \\
\text { a similar-methodology, in a new-study, without } \\
\text { proper-attribution. This often happens, when } \\
\text { studies on a related-topic are repeated with similar- } \\
\text { results, but the earlier-research is not cited } \\
\text { properly. }\end{array}$ \\
\hline & $\begin{array}{l}\text { 6) Replication (Author } \\
\text { Submission Violation) }\end{array}$ & $\begin{array}{l}\text { Submission of a paper to multiple-publications, } \\
\text { resulting in the same-manuscript, being published } \\
\text { more-than-once. This can be an ethical in fraction, } \\
\text { particularly, when a researcher claims that a paper } \\
\text { is new, when it has been published elsewhere. }\end{array}$ \\
\hline & $\begin{array}{ll}7) & \text { Misleading } \\
\text { Attribution (Inaccurate } \\
\text { Authorship) }\end{array}$ & $\begin{array}{l}\text { An inaccurate or insufficient list of authors, who } \\
\text { contributed to a manuscript. This happens when } \\
\text { authors are denied credit, for partial or significant } \\
\text { contributions made to a study, or the opposite- } \\
\text { when authors are cited in a paper, although no } \\
\text { contributions were made. }\end{array}$ \\
\hline & $\begin{array}{l}\text { 8) Unethical } \\
\text { Collaboration } \\
\text { (Inaccurate Authorship) }\end{array}$ & $\begin{array}{l}\text { Happens when people who are working together } \\
\text { violate a code of conduct. Using written-work, } \\
\text { outcomes and ideas, that are the result of } \\
\text { collaboration, without citing the collaborative } \\
\text { nature of the study and participants involved, is } \\
\text { unethical. }\end{array}$ \\
\hline & $\begin{array}{l}\text { 9) Verbatim Plagiarism } \\
\text { (Copy \& paste) - }\end{array}$ & $\begin{array}{l}\text { Copying another peoples' words and works, } \\
\text { without providing proper-attribution, indentation } \\
\text { or quotation marks. This can take two-forms: (a) } \\
\text { plagiarist may cite the source they borrowed from, } \\
\text { but not indicate it is a direct-quote, (b) no } \\
\text { attribution, at all, is provided, essentially claiming } \\
\text { the words of someone else to be their-own. }\end{array}$ \\
\hline & $\begin{array}{l}\text { 10) Complete } \\
\text { Plagiarism (Intellectual- } \\
\text { theft, Stealing) - }\end{array}$ & $\begin{array}{l}\text { An extreme-scenario, when a researcher takes a } \\
\text { study or other-work from another-researcher and } \\
\text { simply resubmits it, under his/her-name. }\end{array}$ \\
\hline
\end{tabular}




\begin{tabular}{|c|c|c|c|c|}
\hline 03. & 2010 & John Walker & Verbatim & $\begin{array}{l}\text { The act of copying text word to word without } \\
\text { mentioning the source, hence rendering the text as } \\
\text { own. }\end{array}$ \\
\hline & & & Sham & $\begin{array}{l}\text { The act of properly citing the source without } \\
\text { paraphrasing the text. }\end{array}$ \\
\hline & & & Purloining & $\begin{array}{l}\text { Presenting entire or significant portion of another } \\
\text { student's work with or without that student's } \\
\text { permission. }\end{array}$ \\
\hline \multirow[t]{2}{*}{04.} & \multirow[t]{2}{*}{2010} & \multirow[t]{2}{*}{ Diane Pecorari } & Prototypical plagiarism & $\begin{array}{l}\text { Using words or ideas from a source without proper } \\
\text { acknowledgement and with the intent to deceive. }\end{array}$ \\
\hline & & & $\begin{array}{l}\text { "Patch writing" (the } \\
\text { term coined by Rebecca } \\
\text { Howard, 1995). }\end{array}$ & $\begin{array}{l}\text { Patch writing is type of plagiarism where the } \\
\text { element of purposeful deception is absent. It } \\
\text { involves copying from a source text and then } \\
\text { changing words, grammatical structure or inserting } \\
\text { synonyms for words in the original text. }\end{array}$ \\
\hline \multirow[t]{2}{*}{05.} & \multirow[t]{2}{*}{2010} & \multirow[t]{2}{*}{ Pritchett } & Paraphrasing plagiarism & Plagiarizing at the stage of paraphrasing. \\
\hline & & & $\begin{array}{l}\text { Word for word } \\
\text { plagiarism }\end{array}$ & Plagiarizing verbatim (word for word copying). \\
\hline
\end{tabular}

Note: Data for Table 1 has been extracted from Turnitin White paper (2016), iThenticate (2013), John Walker (2010), Pritchett (2010), and Diane Pecorari (2010).

\section{Causes of plagiarism}

Weinstein and Dobkin (2002) diagnosed a keen relationship between academics' attitude towards plagiarism and student conduct. They found students prefer deceiving those teachers who show a lenient approach to plagiarism (Weinstein \& Dobkin, 2002).

Batane (2010) and De Jager and Brown (2010) have highlighted factors such as- laziness of students, poor academic writing ability, unawareness of source acknowledgment, faulty education system in terms of assessment design, differences of opinion among administrative staffs as regards implementation of rules- being responsible for plagiaristic behavior of students. Difficulty in understanding and extracting important information from scholarly articles, and deficiency in academic writing have been identified as reasons for plagiarism in the study of Naqvi (2018) on EFL learners in Oman. In the study of Muthanna (2016) it was found that universities in Yemen do not provide students with necessary guidelines on plagiarism. Furthermore, procrastination of students, failure of time management, and lack of exemplary punishment in the institution or lack of confidence were found to incite students of that institution to plagiarize.

Seminal studies on the reasons of plagiarism have been presented in Table 2.

\section{Role of institutions in reducing plagiarism}

One of the crucial factors in shaping the academic performance of students is the contribution of the respective education institution. The current pedagogy in academic writing suggests a leading role of the education institutions to curb plagiarism worldwide (Pecorari \& Petric, 2014). Pecorari (2014) observes a developing realization among the scholars and practitioners that the problem of plagiarism can be tackled by following the path of education rather than punishment.

A holistic stance towards academic integrity considers it more than an individual concern and acknowledges the role of the universities to cater to the development of student understandings and insights into plagiarism or other academic misconducts (Bretag, 2014). Depending only on the integrity of the student is not enough to develop a milieu of academic integrity, the university as a role model of ethical decision construction, should come forth and continue their role of formulating ethical resolutions (Gallant, 2011; Heneyman, 2011).

Scholars have suggested that education institutions should come forward to handle the phenomenon of plagiarism or other academic misconducts aiming at developing an environment of ethical practice which transcends prevention, exposure, and penalty for students (Bretag, 2013). "Individual misconduct" has been defined as the product of a system, influenced by individual, organizational, academic, and societal aspects (Gallant \& Kalichman, 2011). A compact, all-inclusive outlook comprises of initiatives aiming at achieving integrity in all sectors of academic measures, which may take the form of university mission and vision, admission procedure, and clear-cut academic policy (Bretag et al., 2010, Bretag et al., 2013, Carroll \& Appleton, 2001). Approach should be reflected in assessment designs and curriculum preparations (Barrett \& Malcolm, 2006; Devlin, 2002), information tendered during academic orientation, and recurrent visible notices in the campus (Gallant \& Kalichman, 2011). Last but not the least, the adoption and utilization of latest technologies to support students to avert academic misconducts and assist stakeholders to spot malpractices can ensure a congenial healthy academic atmosphere (Bretag, 2013). 
Table 2: Reasons of plagiarism

\begin{tabular}{|c|c|c|c|c|}
\hline SI no. & Year & Author/source & \multicolumn{2}{|c|}{ Reasons of plagiarism } \\
\hline 1. & 2018 & Khadilkar & \multicolumn{2}{|l|}{ Absence of ethical reasoning } \\
\hline 2. & 2017 & Jomaa \& Bidin & \multicolumn{2}{|c|}{ Lack of academic writing skills } \\
\hline 3. & 2016 & $\begin{array}{l}\text { Kayaoglu, Erbay, } \\
\text { Flitner \& Saltas }\end{array}$ & \multicolumn{2}{|c|}{ Poor time management, busy schedule } \\
\hline \multirow[t]{2}{*}{4.} & 2014 & $\begin{array}{l}\text { Newton, Wright, } \\
\text { \& Newton }\end{array}$ & \multirow{2}{*}{\multicolumn{2}{|c|}{ Lack of knowledge and skill in source acknowledgement }} \\
\hline & 2012 & $\begin{array}{l}\text { Voelker, Love, \& } \\
\text { Pentina }\end{array}$ & & \\
\hline 5. & 2014 & $\begin{array}{l}\text { Foltynek, Rybicka } \\
\text { \& Demoliou }\end{array}$ & \multicolumn{2}{|l|}{ Procrastination } \\
\hline 6. & 2014 & Wei et al & \multicolumn{2}{|l|}{ Attaining recognition } \\
\hline 7. & 2010 & $\begin{array}{l}\text { Liao M-T., } \quad \& \\
\text { Tseng C-Y }\end{array}$ & \multicolumn{2}{|c|}{$\begin{array}{l}\text { 1. Insufficient English writing, paraphrasing, and citation skill, } \\
\text { 2. Unfamiliarity with the topic and lack of understanding of the } \\
\text { given text. }\end{array}$} \\
\hline 8. & 2010 & $\begin{array}{l}\text { Batane, } \\
\text { De Jager and } \\
\text { Brown }\end{array}$ & \multicolumn{2}{|c|}{ Deficiency in academic writing } \\
\hline \multirow[t]{3}{*}{9.} & $\begin{array}{l}2011 \\
2008 \\
2007 \\
2005\end{array}$ & $\begin{array}{l}\text { Martin et al } \\
\text { Song-Turner } \\
\text { Devlin \& Gray } \\
\text { Breen \& Maassen }\end{array}$ & $\begin{array}{l}\text { 1. Individual } \\
\text { factors }\end{array}$ & $\begin{array}{l}\text { Age; gender; } \\
\text { Individual and workload; language- } \\
\text { proficiency; Cultural- backdrops; } \\
\text { competition; and self-efficacy. }\end{array}$ \\
\hline & 2010 & $\begin{array}{l}\text { Gullifer \& Tyson } \\
\text { Zimitat }\end{array}$ & $\begin{array}{l}\text { 2. Institutional } \\
\text { factors }\end{array}$ & $\begin{array}{l}\text { Minor or non -prevalent punitive } \\
\text { measures for plagiarism; lack of } \\
\text { academic-honor-codes; } \\
\text { In sufficient-level of knowledge- } \\
\text { application in academic } \\
\text { assessments; and a lack of explicit- } \\
\text { instruction for academic-writing. }\end{array}$ \\
\hline & 2005 & $\begin{array}{l}\text { Bamford } \quad \& \\
\text { Sergiou }\end{array}$ & & \\
\hline 10. & 2007 & Devlin \& Gray & \multicolumn{2}{|c|}{$\begin{array}{l}\text { Students' inefficient time management, } \\
\text { procrastination, and } \\
\text { easy access to online information. }\end{array}$} \\
\hline 11. & 2003 & Park & \multicolumn{2}{|c|}{$\begin{array}{l}\text { 1. Lack of understanding } \\
\text { 2. Efficiency gain } \\
\text { 3. Time management } \\
\text { 4. Personal values/attitudes } \\
\text { 5. Defiance } \\
\text { 6. Students' attitudes towards teachers and class } \\
\text { 7. Denial or neutralization } \\
\text { 8. Temptation and opportunity } \\
\text { 9. Lack of deterrence }\end{array}$} \\
\hline
\end{tabular}

\section{Conclusion}

All over the world various types of plagiarism take place in student writing due to various reasons. But whatever may be the reasons or the kinds, its consequences are dire for students, academics, and the institution. Therefore, awareness of plagiarism should be created among students and their needs should be addressed. Institution should take a facilitating role to acquaint students with conventions of academic writing to build up an academically literate student body which will gradually develop into an asset for the institution and academia.

\section{References}

Bamford, J., \& Sergiou, K. (2005). International students and plagiarism: An analysis of the reasons for plagiarism among international foundation students. Investigations in University Teaching and Learning, 2(2), 17-22.

Barrett, R., \& Malcolm, J. (2006). Embedding plagiarism education in the assessment process. International Journal for Educational Integrity, 2, 38-45.

Batane, T. (2010). Turning to Turnitin to fight Plagiarism among university students. Educational Technology \& 
Society, 13(2), 1-12.

Breen, L., \& Maassen, M. (2005). Reducing the incidence of plagiarism in an undergraduate course: The role of education. Issues in Educational Research, 15(1), 1-16.

Bretag, T., Mahmud, S., Wallace, M., Walker, R., McGowan, U., East, J., . . James, C. (2014). 'Teach us how to do it properly!' An Australian academic integrity student survey. Studies in Higher Education, 39(7), 11501169. doi:10.1080/03075079.2013.777406

Bretag, T., Mahmud, S., M. Wallace, Walker, R., James, C., \& Green, M. (2011). Core elements of exemplary academic integrity policy in Australian higher education. International Journal for Educational Integrity, $7(2), 3-12$.

Bretag, T. (2013). Challenges in Addressing Plagiarism in Education. PLoS Med, 10 (12).

Bretag, T., Mahmud, S., Wallace, M., Walker, R., James, C., Green, M., \& Partridge, L. (2011). Core elements of exemplary academic integrity policy in Australian higher education. International Journal for Educational Integrity, 7(2), 3-12.

Carroll, J., \& Appleton, J. (2001). Plagiarism: a good practice guide. Retrieved from http://www.leeds.ac.uk/candit/plagiarism/brookes.pdf.

Devlin, M (2002). Minimising plagiarism. Centre for Studies in Higher Education, University of Melbourne.

Available: http://www.cshe.unimelb.edu.au/assessinglearning/docs/PlagMain.pdf.

Devlin, M. and Gray, K. (2007). "In their own words: A qualitative study of the reasons Australian university students plagiarize", Higher Education Research and Development, 26, 181-198.

Evans, S., \& Green, C. (2007). Why EAP Is Necessary: A Survey of Hong Kong Tertiary Students. Journal of English for Academic Purposes., 6(1), 3-17. Retrieved from https://doi.org/http://dx.doi.org/10.1016/j.jeap.2006.11.005

Foltýnek, T., Rybička, J., \& Demoliou, C. (2014). Do students think what teachers think about plagiarism? International Journal for Educational Integrity, 10(1), 21-30.

Gallant, T. B. (Ed.) (2011). Creating the ethical academy: A systems approach to understanding misconduct and empowering change in higher education. New York Routledge.

Gallant, T. B., \& Kalichman., M. (2011). Academic ethics: A systems approach to understanding misconduct and empowering change in the academy. In Bertram Gallant 2011 (pp. 27-44). New York: Routledge.

Gullifer, J., \& Tyson, G. A. (2010). Exploring university students' perceptions of plagiarism: A focus group study. Studies in Higher Education, 35(4), 462-481.

Howard, R. M. (1995). Plagiarisms, authorships, and the academic death penalty. College English, 57, 788-805.

Howard, R. M. (1999). Standing in the shadow of giants. Stamford, CT: Ablex.

Howard, R. M. (2007). Understanding "Internet plagiarism". Computers and Composition, 24(1), 3-15. doi: 10.1016/j.compcom.2006.12.005

Hrasky, S., \& Kronenberg, D. (2011). Curriculum redesign as a faculty-centred approach to plagiarism reduction. International Journal for Educational Integrity, 7(2), 23-36.

Hyland, K. (2013). Writing in the university: education, knowledge and reputation. Language Teaching, 46(1), 53-70. doi:10.1017/S0261444811000036

iThenticate. (2013). Research Ethics: Decoding Plagiarism and attribution. Retrieved from thenticate.com/resources/papers/decoding- plagiarism.

Jager, K. D., \& Brown, C. (2010). The tangled web: investigating academic's views of plagiarism at the University of Capetown. Studies in Higher Education, 35(5), 513-528.

Jomaa, N.J., \& Bidin, S.J. (2017). Perspective of EFL doctoral students on challenges of citations in academic writing. Malaysian Journal of Learning and Instruction, 14 (2), 177-209.

Khadilkar, S. S. (2018). The Plague of Plagiarism: Prevention and Cure!!! The Journal of Obstetrics and Gynecology of India, 68(6), 425-431.

Kim, H. Y. (2011). International Graduate Students' Difficulties: Graduate Classes as a Community of Practices. Teaching in Higher Education., 16(3), 281-292. Retrieved from https://doi.org/10.1080/13562517.2010.524922.

Liao, M.-T., \& Tseng, C.-Y. (2010). Students' behaviors and views of paraphrasing and inappropriate textual borrowing in an EFL academic setting. Journal of Pan-Pacific Association of Applied Linguistics, 14(2), 187211.doi:10.1007/s40979-015-0001-7.

Logue, R. (2004). Plagiarism: The internet makes it easy. Nursing Standard, 18(51), 40-43. doi:10.7748/ns2004.09.18.51.40.c3685 PMID:15487496.

Luchini, P. L. (2010). Evaluating the effectiveness of a complimentary approach to teaching writing skills. International Journal of Language Studies (IJLS), 4(3), 73-92.

MacLennan, H. (2018). Student Perceptions of Plagiarism Avoidance Competencies: An Action Research Case Study. Journal of the Scholarship of Teaching and Learning, 18(1), 58-74. doi:10.14434/josotl.v18i1.22350.

Martin, B. (1994). Plagiarism: a misplaced emphasis. Journal of Information Ethics, 3(2), 36-47. 
Martin, D., Rao, A., \& Sloan, L. (2011). Ethnicity, acculturation, and plagiarism: A criterion study of unethical academic conduct. Human Organization, 70 (1), 88-96.

Muthanna, A. (2016). Plagiarism: A Shared Responsibility of All, Current Situation, and Future Actions in Yemen. Accountability in Research, 23(5), 280-287. doi:10.1080/08989621.2016.1154463.

Naqvi, S. (2018). Challenges of Integrating Academic Sources in Assessed Assignments: A Case of Arab EFL Learners. Paper presented at the Arab World English Journal (AWEJ).

Newton, F., Wright, J., \& Newton, J. (2014). Skills training to avoid inadvertent plagiarism: Results from a randomized control study. Higher Education Research and Development, 33(6), 1180-1193.

Park, C. (2003). In other (People's) words: Plagiarism by university students: Literature and lessons. Assessment and Evaluation in Higher Education, 28(5), 471-488.

Pecorari, D., \& Petrić, B. (2014). Plagiarism in second-language writing. Language Teaching, 47(03), 269 - 302. doi: $10.1017 / \mathrm{S} 0261444814000056$.

Pecorari, D. (2010). Academic writing and plagiarism: a linguistic analysis. In (paperback edition ed.). London: Continuum.

Phakiti, A., \& L, L. (2011). General Academic Difficulties and Reading and Writing Difficulties Among Asian ESL Postgraduate Students in TESOL at an Australian University. RELC Journal., 42(3), 227-264. Retrieved from https://doi.org/10.1177/0033688211421417.

Pre, A., \& Belter, R. (2009). A strategy to reduce plagiarism in an undergraduate course. Teaching of Psychology, 36(4), 257-261. doi: doi:10.1080/00986280903173165.

Pritchett, S. (2010). Perceptions about plagiarism between faculty and undergraduate students. San Diego, CA: Alliant International University.

Ravichandran, S., Kretovics, M., Kirby, K., \& A. Ghosh. (2017). Strategies to Address English Language Writing Challenges Faced by International Graduate Students in the US. Journal of International Students, 7(3), 764786. Retrieved from https://doi.org/10.5281/ZENODO.570033

Salgado, A., \& Bassendowski, S. (2005). Is plagiarism creating an opportunity for the development of new assessment strategies? International Journal of Nursing Education Scholarship, 2 (1), 1-9.

Song-Turner, H. (2008). "Plagiarism: Academic dishonesty or 'blind spot' of multicultural education?". Australian University Review, 50(2), 39-51.

Szabo, A., \& J. Underwood. (2004). Cybercheats. Active Learning in Higher Education, 5(2), 180-199. doi:10.1177/ 1469787404043815.

Tommaso, L., \& Roig, M. (1995). Are college cheating and plagiarism related to academic procrastination? Psychological Reports, 77(2), 691-698. doi: 10.2466/pr0.1995.77.2.691.

Turnitin. (2016). The Plagiarism Spectrum: Instructor Insights into the 10 Types of Plagiarism.

Voelker, T., Love, L., \& Pentina, I. (2012). Plagiarism: What they don't know? Journal of Education for Business, 87, 36-41. doi: 10.1080/08832323.2011.552536.

Walker, J. (2010). Measuring plagiarism: researching what students do, not what they say they do. Studies in Higher Education, 35(1), 41-59. doi:10.1080/03075070902912994.

Wan, R., Nordin, S., Halib, M. and Ghazali, Z. (2011). Plagiarism among undergraduate students in an engineering-based university: An exploratory analysis. European Journal of Social Sciences, 25 (4), 537-549.

Wang, Y. W. (2008). University students' online plagiarism. International Journal on E-Learning, 7(4), 743-757.

Wei, T., Chesnut, S. R., Barnard-Brak, L., \& Schmidt, M. (2014). University students' perceptions of academic cheating: Triangulating quantitative and qualitative findings. Journal of Academic Ethics, 12, $287-298$. doi:10.1007/s10805-014-9219-X.

Weinstein, J., \& Dobkin, C. (2002). Plagiarism in U.S. higher education: Estimating. Retrieved from: http://webdisk.berkeley.edu/ Weinstein/Weinstein-JobMarketpaper

Zimitat, C. (2008). A student perspective of plagiarism. In T. S. Roberts (Ed.), Student plagiarism in an online world: Problems and solutions. Information Science Reference: Hershey, PA.

\section{Biography}

Ms. Nur-E Hafsa is working as a Lecturer of English in a leading private university in Bangladesh. She achieved her Distinction in master's degree in Applied Linguistics from Curtin University of Technology, Western Australia. Before that she completed her B.A and M.A from Dhaka University, Bangladesh which is the oldest and prestigious academic institution of Bangladesh. Her area of interests are academic literacy, academic writing, and plagiarism. 